\title{
CONSERVATIVE MODERNISATION AND EUROPEAN INTEGRATION: FROM SILENCE TO SALIENCE AND SCHISM
}

\author{
Dr Philip Lynch \\ Department of Politics and International Relations \\ University of Leicester \\ LEICESTER. LE1 7RH. \\ Email: PLL3@le.ac.uk
}

Tel: 01162522712

\begin{abstract}
The re-emergence of European integration as a difficult issue for the Conservative Party exposed the limits of David Cameron's modernisation project. In opposition, Cameron had defused the EU issue by lowering its salience but this suppressed rather than effectively addressed the issue, allowing Eurosceptics who favour withdrawal or fundamental renegotiation to shape the agenda. In office, new and familiar challenges emerged. The Eurozone sovereign debt crisis changed the dynamics of the UK's relationship with the EU. Domestically, coalition with the Liberal Democrats and dissent from Eurosceptic Conservative MPs restricted Cameron's room for manoeuvre, while the rise of the UK Independence Party added a new dimension to the problems the EU issue poses for the Conservatives. Cameron responded by promising that if the Conservatives win the 2015 general election, he will negotiate a 'new settlement' in the EU and hold an 'in-out' referendum. This article assesses whether this position amounts to a belated modernisation of Conservative policy that might both resolve intra-party divisions and settle the question of the UK's place in the EU.
\end{abstract}

KEY WORDS: Conservative Party, modernisation, European integration, Euroscepticism. 
The re-emergence of European integration as a difficult and divisive issue for the Conservatives exposed the limitations of David Cameron's modernisation project. Cameron's policy on European integration has been punctuated by paradoxes. Having initially urged his party to stop 'banging on about Europe' (Cameron, 2006), the UK's relationship with the European Union (EU) became a defining issue for Cameron. His pragmatic Euroscepticism initially reassured potential critics of modernisation but, by suppressing rather than addressing the EU issue, those who favoured withdrawal or fundamental renegotiation were afforded space to develop their position and set the agenda - and Cameron would later play catch-up. Modernisation also opened up political space into which moved a reinvigorated UK Independence Party (UKIP), creating an historic schism on the Right.

Cameron described himself as a 'practical, sensible' Eurosceptic (Kirkup, 2010) early in his premiership, but raised the stakes dramatically in 2013 by pledging to negotiate a new settlement with the EU and hold an 'in-out' referendum. He was following a well-trodden path of adopting imprecise positions, deferring decisions and promising referendums in order to dampen intraparty conflict (Lynch and Whitaker, 2013a). Yet it has potentially momentous consequences for the Conservatives, the UK and the EU. If successful, Cameron's approach could heal Conservative divisions, legitimise their EU policy and establish a clearer relationship with the EU. But it also risks intensifying intra-party divisions and bringing about withdrawal from the EU.

\section{The Politics of Support and Politics of Power}

This article employs Andrew Gamble's distinction between the 'politics of support' and the 'politics of power' (Gamble, 1994) to assess the problems that the EU issue posed for the 
Conservatives and Cameron's modernisation. The politics of support concerns a party's need to 'win support from voters, organised interests and their own party members, mobilising a coalition that can win elections and establish a claim to political moral and intellectual leadership' (Gamble, 1994, 8). The politics of power concerns successful government 'which involves harmonising their popular mandate with the realities of managing the state machine and coping with the pressures placed upon policy by the structural constraints of the domestic polity and the world political economy’ (Gamble, 1994, 8). A successful electoral project does not automatically produce an effective governing project, but effective statecraft (Bulpitt, 1986) requires success in both the politics of support and politics of power.

For more than fifty years, European integration has posed significant problems for Conservative statecraft in both the politics of support and politics of power. In the former, the party has suffered major internal divisions over its approach to European integration. Leaders' attempts to broker compromise positions or defer decisions have temporarily quelled, but never fully resolved, these divisions. Disunity has in turn damaged the Conservatives' reputation for governing competence, notably during disputes over membership of the Exchange Rate Mechanism (ERM) and Economic and Monetary Union (EMU) under Margaret Thatcher and John Major. Divisions have also made it difficult for the party to exploit the EU issue in elections, even when their position is close to public opinion (Evans, 1998). The rise of UKIP, which seeks withdrawal from the EU, further reduces the Conservatives' prospects of establishing issue ownership.

In the politics of power, the extension of EU competences in economic, social and justice and home affairs policy reduced the autonomy of Conservative governments and challenged their political economy. The switch from a domestic to a European economic strategy when the UK joined the ERM (Bulpitt, 1992) proved an unhappy interlude, with ERM exit and growing 
opposition to EMU pushing the party in a Eurosceptic direction. Conservative governments have since tried to limit EU encroachment by defending the national veto and securing opt-outs from new policies, but have neither halted nor reversed the momentum towards 'ever closer union'.

As well as facing difficulties in both the politics of support and politics of power, Conservative leaders have struggled to strike the right balance between them. Short term tactical manoeuvres have temporarily reduced intra-party dissent or boosted the party's fortunes in competition with its rivals. But a succession of tactical positions has not amounted to an effective strategy to either build a domestic consensus on EU policy or enhance British influence in the EU and, indeed, has often undermined efforts to do so.

\section{Conservative modernisation and European integration}

Modernisation is an ambiguous concept. At its most elusive, it is little more than an 'empty signifier' bereft of substantive content (Byrne, Foster and Kerr, 2012). For many studies of Cameron's modernisation, it involves changes in personnel, organisation, ideology and policy (McAnulla, 2010; Bale, 2011). This article views modernisation as conscious, far-reaching adaptation to significant changes in the environment in which the party operates, incorporating both the politics of support and the politics of power. Rather than routine adaptation to fluctuations in party competition, it involves the reappraisal of party tradition, ideology and strategy in response to changes to the state, economy and society (Kenny and Smith, 1997; Dommett, 2015). Renewal by the Conservatives under Thatcher and Labour under Tony Blair are prime examples of modernisation as they addressed crises of party identity caused by changes in the politics of support and politics of power. Cameron's modernisation has not been as radical or effective. 
Despite its growing importance to Conservative statecraft, European integration was peripheral to two of the three major modernisation projects undertaken by the party in opposition since 1963 . The exception is Edward Heath's spell as leader of the opposition. European Economic Community (EEC) entry was central to Heath's strategy, which first emerged under the Macmillan government, for reviving the party, state and economy. As 'the party of Europe', the Conservatives offered a fresh narrative that addressed the relative economic decline of the UK and its dated institutions. Yet concerns among voters and Conservative MPs about the costs of entry saw enthusiasm for EEC entry muted in Conservative campaigning (Bale, 2012, 141). The Heath period is the only one in which European integration was seriously considered, never mind promoted, as part of a wide-ranging overhaul of ideology, policy and strategy. Little consideration was paid to the EEC in the policy renewal undertaken when Thatcher was in opposition. Only after resolution of the British Budget Question in 1984 did the Thatcher governments seek to upload their domestic economic policy preferences to the European level through the single market programme. But this strategic approach faltered when other Member States pushed for EMU and Conservative divisions re-opened.

In opposition, Cameron approached the EU issue primarily in relation to the politics of support, lowering its salience in order to rebrand the party and minimise intra-party divisions. The reworking of Conservative ideology and policy in response to political, economic and social change was geared towards the domestic realm, albeit with a new interest in international development and climate change, with the EU dimension comparatively neglected. Only limited progress was made in considering how a future Conservative government would deal with the constraints imposed by European integration.

\section{'Not banging on': the EU issue, 2005-10}


Euroscepticism is hardwired into the ideology and identity of the contemporary Conservative Party. The arch modernisers - first Michael Portillo, Francis Maude and Oliver Letwin, then Cameron, George Osborne, Nick Boles and Steve Hilton - are Eurosceptic. A modernisation project that sought to rid the party of its Euroscepticism would have been unpalatable, even for a party as skilled historically at pragmatic adaptation as the Conservatives. The EU was a low key issue in the 2005 leadership election, but Cameron's promise to remove Conservative MEPs from the European People's Party-European Democrats (EPP-ED) group in the European Parliament broadened his support base (Lynch and Whitaker, 2008, 34). Without the backing of Eurosceptic MPs from the Right of the party, Cameron's mandate would have been fragile.

The break from the EPP-ED was delayed until after the 2009 European elections when the European Conservatives and Reformists Group (ECR) was formed. Its other main parties, the Polish Law and Justice Party and the Czech Civic Democrats, shared the Conservatives' free market liberalism and soft Euroscepticism but the social conservatism of Law and Justice and other smaller parties sat uneasily with Cameron's liberalism (Bale et al, 2010). In leaving the EPP-ED, Cameron put the politics of support ahead of the politics of power. The Conservatives lost influence in the European Parliament by leaving the largest group, although they chaired the Internal Market Committee and had some leverage over single market legislation (Whitaker and Lynch, 2014). But even if they had remained in the EPP-ED, the Conservatives would no longer have been the second largest party and opposition within the group to their position on financial services was growing. Relations with centre-right parties in Germany and France were strained but Cameron built bridges with Angela Merkel. The ECR expanded after the 2014 European elections by admitting the radical right Danish People's Party and Finns Party and, at the risk of antagonising Merkel, the Alternative for Germany. No parties defected from the EPP. 
At his first annual conference as Conservative leader, Cameron told his party that instead of 'talking about the things that most people cared about, we talked about what we cared about most ... banging on about Europe' (Cameron, 2006). In fact, the Conservatives had already lowered the salience of the issue since William Hague's 2001 'save the Pound' election campaign. Iain Duncan Smith had adopted a harder but quieter policy (Bale, 2006) and the EU did not feature prominently in the 2005 election under Michael Howard. Labour had also defused the issue by ruling out EMU entry and matching the Conservative commitment to a referendum on the EU Constitutional Treaty (Oppermann, 2008). It barely featured in the Conservatives' 2010 election campaign when only 1 per cent of voters identified the EU as the most important issues. Given this, the hardening Euroscepticism of Conservative voters and the alternative offered by UKIP, Cameron had good reason to downplay it (Lynch and Whitaker, 2013b).

Conservative policy and discourse on the EU did not undergo the radical changes seen in other areas. Cameron maintained much of the soft Eurosceptic position developed by his predecessors. Major had threatened to veto further transfers of powers, sought opt-outs and promised a referendum should his party recommend EMU entry. Hague's 'in Europe, not run by Europe' formula then brought commitments to referendums on major EU treaties, a reaffirmation of parliamentary sovereignty and limited repatriation of competences. EMU policy was finally settled when Duncan Smith ruled out entry. Cameron maintained the party's opposition to the Lisbon Treaty but made limited changes to other aspects of EU policy, watering down the commitment to repatriate social and employment policy, and proposing reform of the Common Fisheries Policy rather than repatriation.

Policy towards the EU was linked to the modernising agenda in Cameron's first major speech on the subject, in which he urged the EU to focus on globalisation, global warming and global poverty, while rejecting an extension of its competences (Cameron, 2007a). Identifying global 
poverty as an EU priority signalled a departure from the position taken by Howard who had wanted international aid policy to be repatriated.

Elsewhere, Cameron's discourse on the EU is similar to that of his predecessors (Daddow, 2015). There is some synergy between the Cameroon critique of the state and of the EU, although this has not been fully developed. Cameron talked of a 'post-bureaucratic' age in which 'big government' is ineffective as a provider of many public goods, and was similarly critical of EU centralisation and the regulatory zeal of the European Commission. Old assumptions about European integration are, he contended, out-dated given the diversity of the EU, concerns about its legitimacy, and globalisation: 'for too long, the European Union has tried to make reality fit its institutions. But you can only succeed in the long run if the institutions fit the reality' (Cameron, 2011). His vision is of a flexible EU 'that must be able to act with the speed and flexibility of a network, not the cumbersome rigidity of a bloc' (Cameron, 2013).

The Conservative leadership claims that European integration has weakened the bonds between government and the people, undermining representative democracy and adding to popular dissatisfaction with the political process (Gifford, 2012). Further integration exacerbates the problem as citizens identify with national institutions. Cameron's opposition to Jean-Claude Juncker's nomination as President of the European Commission was a verdict on his personal qualities and a rejection of the Spitzenkandidat process that linked the choice of Commission President to the outcome of elections to the European Parliament. Conservative remedies for the lack of legitimacy and accountability in the EU reflect the party's continued emphasis on the nation state as the locus of democratic legitimation: subsidiarity, an enhanced role for national parliaments and referendums on the transfer of competences to the EU. 
The Conservative position on sovereignty has evolved since the 1980s. Whereas Thatcher and Major rejected calls for a referendum on the Single European Act and Maastricht Treaty respectively, in opposition the party proposed referendums on new EU treaties. In opposing the Lisbon Treaty, Cameron developed Howard's focus on democracy and trust in government, downplaying the traditional emphasis on national sovereignty. But Cameron's claim that his commitment to a referendum on Lisbon was a 'cast iron guarantee' (Cameron, 2007b) backfired for, when the treaty was ratified by all Member States, he announced that there would be no retrospective referendum (Cameron, 2009). Instead, a Conservative government would seek 'British guarantees' on social and employment policy, the Charter of Fundamental Rights and criminal justice. In 1996 Major pledged that a Conservative government would hold a referendum should it recommend EMU entry. By 2010, the Conservative manifesto was promising a referendum on any treaty transferring powers to the EU and on decisions such as EMU entry or removal of border controls. It also promised a Sovereignty Bill to reaffirm the supremacy of the Westminster Parliament. The new Conservative position thus embraced both parliamentary and popular sovereignty (Wellings, 2012).

\section{Back with a bang: EU policy since 2010}

Hopes for a low key start to relations with the EU were dashed by the Eurozone sovereign debt crisis. This proved a critical juncture with Eurozone states agreeing a 'roadmap' for the completion of EMU that hastens the emergence of a multi-speed Europe. In response, the government accepted that Eurozone states should strengthen EMU in order to resolve the crisis, arguing that this was in the interests of the UK as well as the EU, and supported pan-European austerity measures (Osborne, 2014). Suggestions from Eurosceptics that the government argue for a dissolution or streamlining dissolution of the Eurozone, and demand redress of UK grievances as the price for its support were rejected. But the UK was unwilling to pay for, and would not 
take part in, measures to strengthen the euro. It refused to join the European Stability Mechanism and Euro Plus Pact, and did not sign the 2012 Treaty on Stability, Coordination and Governance (the 'fiscal compact'). On the latter, Cameron vetoed an EU fiscal compact treaty in December 2011 when his eleventh-hour demands for additional safeguards on the single market and financial services were rejected. But it was apparent that other governments were determined to press on with or without British approval. Within months, Cameron accepted that 25 Member States (but not the UK or Czech Republic) would sign an intergovernmental treaty that permitted recourse to the European Court of Justice (ECJ) but reserve the right to launch future legal objections. Cameron struggled with the differing demands of the politics of support and politics of power, his veto pleasing his party and supporters but angering other EU leaders.

The government sought additional guarantees to ensure that further integration would neither undermine the single market nor discriminate against non-Eurozone states. It feared that after the November 2014 changes to qualified majority voting, Eurozone states might caucus, arranging to vote as a bloc to protect their interests on measures that apply to the EU as a whole. The UK secured a system of double majority voting in the European Banking Authority with proposals requiring support from a majority of both Eurozone and non-Eurozone states (Dashwood, 2013). Of particular concern was the threat to the City of London posed by EU regulation of financial services. A weakening of the City would have adverse consequences for the Conservative politics of power given its importance to Conservative political economy and the politics of support given business backing for the party. The UK launched a series of challenges in the ECJ, notably on the Financial Transaction Tax (set to be introduced in ten Member States under the EU's enhanced cooperation procedure), requirements for clearing houses with high-volume euro transactions to locate within the Eurozone, and a cap on bankers' bonuses. The government withdrew the latter when the ECJ's Advocate General rejected its arguments. 
The coalition's support further integration in the Eurozone marked an important change in British strategy. Previous governments had feared the development of a two-speed Europe in which the UK was a semi-detached member outside the core. The price for support for further integration was safeguards for the UK and on the single market but it was not certain that these demands would be met in full (hence the fiscal compact veto) and, even if they were, UK influence and the economic liberal case more broadly risked being weakened. Furthermore, the Conservative vision of a flexible EU is not only one in which some Member States forge ahead with further integration, but also one in which some powers flow back to national governments - yet there was little by way of a reciprocal repatriation of powers.

Differentiation in the EU also became more pronounced in justice and home affairs. The Lisbon Treaty gave the UK the right to opt-in or opt-out of 133 police and criminal justice measures before they became subject to enforcement by the European Commission and European Court of Justice in December 2014. The coalition exercised this block opt-out in July 2013 but opted back in to 35 measures, including the European Arrest Warrant (HM Government, 2013). Ministers regarded it as valuable in speeding up the process of extradition but had concerns about its use for minor offences, the lengthy pre-trial detention of suspects and extradition for conduct that is not criminal in the UK.

Balancing the Coalition Agreement's objectives of constructive engagement and protection of national sovereignty proved difficult (HM Government, 2010, 19). The government had some success in promoting British interests. It helped bring about a real term cut in the EU's 2014-20 Multiannual Financial Framework, but the UK's net annual contribution to the EU rose from $£ 7.4$ billion in 2010 to $£ 10.5$ billion in 2013 before falling back (HM Treasury, 2014). The UK agenda was also furthered with progress being made on completing the digital single marker and markets in energy and services, and negotiations opening on the Transatlantic Trade and Investment 
Partnership (TTIP). Overall, however, the UK was less influential in the EU at the end of the coalition's term in office than it had been at the outset. Cameron's handling of the fiscal compact veto and nomination of Juncker nomination were criticised in other Member States.

Domestically, the European Union Act 2011 introduced a 'referendum lock' requiring future treaties transferring powers from the UK to the EU to be put to a binding referendum after receiving parliamentary approval. A referendum will also be held if, for example, the UK joins the euro or abolishes border controls, and in some cases where the EU uses the simplified revision procedure or enabling clauses to adopt qualified majority voting. Referendums were not, however, required on enlargement, Eurozone bailout funds, the fiscal compact or opting back in to police and criminal justice measures. Requirements for parliamentary approval of EU action were also strengthened. However, the government was later criticised for bypassing scrutiny of the police and criminal justice block opt-out. Finally, Section 18 of the Act states that EU law only takes effect in the UK through the will of parliament, but this does not change the relationship between UK and EU law and has little practical effect (Craig, 2011). Yet the Act did not fit into a wider programme of constitutional modernisation.

\section{Challenges Old and New: Dissent, Coalition and the Rise of UKIP}

Domestic developments, familiar and new, added to the difficulties that European integration poses for Cameron's Conservatives. Coalition restricted Cameron's room for manoeuvre. Manifesto commitments on additional assurances on the Lisbon Treaty were dropped during coalition negotiations. In government, the Liberal Democrats urged a constructive approach and tried to prevent Cameron from straying beyond the coalition agreement (Goes, 2014). Nick Clegg was angered by Cameron's fiscal compact veto but then persuaded him to accept that the ECJ be permitted to enforce excessive debt procedures. On the block opt-out on police and criminal 
justice, Liberal Democrat ministers ensured that the government would seek to opt back in to some measures. The Liberal Democrats refused to allow the government to introduce legislation on an 'in-out' referendum and opposed Conservative Private Member's Bills on the issue.

\section{Conservative divisions}

In opposition, Cameron's pragmatic Euroscepticism had helped bridge the divide between modernisers and the Conservative Right. This uneasy truce did not survive into government as a toxic combination of factors re-opened divisions on European integration: the Eurozone crisis, the dilution of Conservative policy in coalition, the growth of hard Euroscepticism on the Conservative benches, ineffectual party management and the rise of UKIP.

In the first three sessions of the 2010 parliament (May 2010-May 2014), 101 different Conservative MPs rebelled on EU issues and 44 votes on EU issues saw a rebellion. Among the rebels were consistent critics of Cameron's modernisation project and 60 MPs from the 2010 intake. The largest ever Conservative rebellion on European integration occurred in October 2011 when 81 Conservative MPs defied a three-line whip to support a backbench motion on policy repatriation and a referendum (Cowley and Stuart, 2012). The government was then defeated on a motion on the EU budget in October 2012 when 53 Conservatives voted with Labour to support an amendment demanding a real terms cut. A major rebellion was averted when Cameron took the unprecedented step of allowing his backbenchers a free vote on an amendment to the motion on the 2013 Queen's Speech regretting the absence of a referendum Bill (Cowley and Stuart, 2014, 5). 116 Conservative MPs duly supported the amendment. Cameron also threw his weight behind Private Member's Bill introduced by James Wharton and Bob Neill which would require an 'in-out' referendum to be held by 2017 . Neither reached the statute book. 
Intra-party dissent on Europe is more likely in government than in opposition because individual governments cannot control the EU agenda, must take decisions on divisive issues and make compromises in EU negotiations (Lynch and Whitaker, 2013a). New problems, such as the EU's demand for an additional $£ 1.7$ billion budget contribution from the UK, emerged to fuel Eurosceptic ire. Cameron initially held the line in face of Eurosceptic demands, imposing a threeline whip on the 2011 EU referendum motion, but thereafter made concessions. Rather than satisfying Eurosceptic demands, these brought new threats of rebellion by dissenters who expected that Cameron would give more ground.

The fault line in the Conservative Party is no longer between Europhiles and Eurosceptics, but between 'soft Eurosceptics' - who oppose further integration but support EU membership - and 'hard Eurosceptics' who are opposed in principle to European integration (Szczerbiak and Taggart, 2004). Heppell calculates that 50 per cent of Conservative MPs in the 2010 parliament are soft Eurosceptic and 26 per cent hard Eurosceptic (Heppell, 2013, 347). With differences between Conservative Eurosceptics revolving around the extent of policy repatriation, a finergrained typology (Lynch and Whitaker 2013a, 319) locates them on a spectrum:

- $\quad$ outright rejectionists - support withdrawal from the EU as a matter of principle, and want it to be achieved at the earliest opportunity.

- maximal revisionists - demand a fundamental renegotiation of the UK's relationship with the EU. Preferred outcomes differ, but include new relationships based on free trade similar to the Swiss or Norwegian models.

- minimal revisionists - favour a limited repatriation of existing EU competences and a reversal of 'ever closer union'. 
- $\quad$ minimalists - oppose further integration and look to exploit existing opportunities for reform (e.g. opt-outs and protocols, subsidiarity, the 'yellow card' system for national parliaments, challenges in the ECJ).

Operationalizing any typology of Eurosceptic attitudes within parties is problematic. Public statements and parliamentary votes may not reveal the true position of MPs. Warnings from the leadership against departures from the official line meant that many Conservatives said little on the EU issue at the 2010 election. Party discipline and career considerations then disguised the nature and extent of Eurosceptic attitudes within the parliamentary party. Public support for a referendum and renegotiation may then be code for withdrawal. The boundary between 'outright rejectionists' and 'maximal revisionists' is thus blurred: the latter may favour changes so extensive that they amount to withdrawal.

Cameron's EU policy falls into the minimalist category, but his Bloomberg speech promises a shift to the minimal revisionist position. However, the centre of gravity in the Conservative Party has already moved towards the maximal revisionist position. Cameron's unwillingness to set out a detailed agenda for EU reform created space for Eurosceptics to develop their own demands (Copsey and Haughton, 2014). While Cameron's modernisation project avoided the EU issue, others seized the opportunity to modernise the Eurosceptic case. A new breed of Eurosceptic MP entered the House of Commons in 2010 and went further than the Conservative leadership in developing a discourse embracing democracy, liberty and free trade which presented the EU as outmoded and alternatives to it as better suited to the era of globalisation.

Outright rejectionists regard meaningful renegotiation as impossible and claim that Cameron's reform objectives would barely alter the status quo (Hannan, 2014). Only a small number of Conservative MPs have publically demanded immediate withdrawal from the EU. Many more 
have signalled support for the maximal revisionist position of fundamental renegotiation. The most significant grouping here is the Fresh Start Project (FSP) whose first meeting attracted more than 100 MPs, primarily from the 2010 intake. It initially had tacit support from the whips as a vehicle for developing the Eurosceptic case, but many of its members have since rebelled on EU issues. FSP proposes major changes to the UK's relationship with the EU (Fresh Start Project, 2012, 2013a, 2013b). Those which go beyond Cameron's position include an opt-out from the Charter of Fundamental Rights, an emergency brake mechanism (e.g. in financial services), unpicking ECJ judgements and the repatriation of regional policy. It also suggests that the UK unilaterally suspend its EU obligations until reforms are achieved. Support for the maximal revisionist position was evident when 95 Conservative MPs wrote to Cameron urging him to accept the European Scrutiny Committee's proposals for a parliamentary veto over current and future EU law. It would give the House of Commons the power to decide that proposed EU legislation should not apply to the UK and to disapply parts of the existing aquis (European Scrutiny Committee, 2013). Support for the single market, once a staple Conservative position, is waning among revisionist Eurosceptics who regard its excessive regulation as hindering British competitiveness (Cash and Jenkin, 2013). They propose an alternative 'hyperglobalist' political economy (Baker et al, 2002) in which the UK, no longer 'shackled to the corpse' of a declining Eurozone, would flourish by developing new trade relationships with emerging economies and/or the Anglosphere.

There has been little dissent from Europhile Conservatives, whose number has declined significantly since the 1990s. European Mainstream, numbering some 30 MPs, was established in 2013 and published a series of essays that are reformist rather than supportive of deeper integration (European Mainstream Group, 2014)

The rise of UKIP 
The rise of UKIP poses a new and serious challenge to Conservative modernisation. Originally dismissed by Cameron as 'fruitcakes, loons and closet racists' (Carlin, 2006), UKIP consistently scored over 10 per cent in opinion polls from 2012 and topped the popular vote in the 2014 European elections. By attracting significant support from former Conservative voters, UKIP posed a short-term threat to the party, but UKIP's rise is also a symptom of, and a contributory factor to, longer-term problems for the Conservatives.

UKIP poses the most significant challenge to the Conservatives' dominance on the Right of British politics. Historically, external challenges from the Right have been short-lived and potential rivals have often been absorbed by the Conservatives. The most significant challenge from the Right to the political orthodoxy - Thatcherism - came from a faction within the Conservative Party. The defection to UKIP and subsequent by-election successes of Douglas Carswell and Mark Reckless changed the dynamics by providing a viable exit strategy for MPs on the Conservative Right.

The politics of nationhood was a Conservative strength for much of the twentieth century, but identity politics - European integration, immigration and the future of the Union - have become difficult for the party (Lynch, 1999). UKIP's focus on identity politics exacerbates these problems. Euroscepticism remains central to UKIP's appeal and identity, although it has broadened its narrative and support base. UKIP has been able to frame debates on the EU and immigration by linking the issues together, making it more difficult for the Conservatives to both lower their salience and claim policy success. The Conservatives' efforts to counter UKIP's appeal on the EU issue have been largely ineffective (Lynch and Whitaker, 2013b). 
UKIP's success has brought the shortcomings of Cameron's modernisation project into starker relief. In opposition, Cameron recognised that the Conservatives could only win from the centre ground, but was unable to attract sufficient support from the middle class, women and ethnic minority voters to deliver a parliamentary majority. This shortfall was then aggravated by the leakage of support to UKIP. UKIP exploited Conservative vulnerabilities on issues such as the EU, immigration and gay marriage, and benefited from government failings on valence issues (e.g. the 2012 budget 'omnishambles'). In short, Cameron failed to reproduce the alchemy that saw Thatcher and Blair persuade supporters of rival parties to switch sides while retaining much of their own core support

The Conservatives lost significantly more of their 2010 general election support to UKIP than Labour or the Liberal Democrats. Data from the British Election Study's Continuous Monitoring Survey (CMS) for the period June 2010 to April 2013 showed that 42\% of UKIP supporters recalled voting for the Conservatives in 2010. UKIP took a higher proportion of voters from the Conservatives since 2012 than it had taken from Labour under Blair or Brown. Ahead of the 2015 general election, some $20 \%$ of Conservative 2010 voters were saying that they would vote for UKIP, with those who disapprove of EU membership, are in working class occupations and are older being most likely to defect. Webb and Bale (2014) also found many Conservative Party members willing to countenance voting for UKIP.

UKIP's rise diminishes the Conservatives' cross-class, national appeal. The economic interests and social characteristics of working class UKIP voters may be similar to 'Old Labour' voters (Ford and Goodwin, 2014), but their political attitudes place them on the Right. Some are exConservatives, others are the archetypal blue collar voters that the Conservatives used to attract but who now seem beyond their reach. Thatcherism's combination of an economic appeal to aspirant working class voters with patriotic, social conservative values won over the 'Tebbit 
Tories'. Should working class conservatives take a revised 'Tebbit Test'- which party do you support, the Conservatives or UKIP? - many would choose UKIP. Conservative efforts to attract blue collar voters are also harmed by UKIP's populist rhetoric which depicts the party as out of touch with ordinary people.

\section{Renegotiation and an 'In-Out' Referendum}

In a keynote speech (the 'Bloomberg speech') in January 2013, Cameron stated that should the Conservatives win the 2015 general election he would negotiate 'a new settlement' for the UK in the EU and then hold a referendum on whether the UK should remain in the EU (Cameron, 2013). Renegotiation and 'in-out' referendum mark a new attempt to marry the politics of power and the politics of support, providing the conditions for effective Conservative statecraft by reforming the UK's relationship with the EU then gaining popular approval for it.

A 'new settlement'

Cameron rejected alternatives to EU membership and made it clear that his strategic objective was to remain in a reformed EU. The Bloomberg speech set out five broad principles for the development of the EU - competitiveness, flexibility, power flowing back to Member States, democratic accountability and fairness for non-Eurozone states. It did not specify areas for repatriation (the term was not used) and nor did the government's Review of the Balance of Competences which was a technocratic exercise rather than one designed to generate policy recommendations.

Cameron subsequently identified seven key objectives (Cameron, 2014a). Achieving reform will be difficult if this requires full-scale treaty change or if the UK is perceived to be asking for 
special treatment or using threats of exit to get its way. It will be more likely if the UK government seeks to find common ground with other Member States as part of a wider (but limited) reform project.

Many of Cameron's seven objectives chime with concerns of other Member States, but some may require treaty change. The first objective, 'powers flowing away from Brussels, not always to it' might be limited to repeal of particular rules (e.g. the Working Time Directive) or encompass the repatriation of whole policy areas. Another objective, 'no to ever closer union', would require treaty change. The June 2014 European Council stated that 'the concept of ever closer union allows for different paths of integration for different countries, allowing those that want to deepen integration to move ahead, while respecting the wish of those who do not want to deepen any further' (European Council, 2014). But it made no mention of repatriating powers. Cameron's desire for national parliaments to be able to work together to block EU legislation reflected proposals to upgrade the current 'yellow card' system. Another objective, UK police forces and justice systems 'unencumbered by unnecessary interference from the European institutions, including the European Court of Human Rights' goes beyond the EU. Proposals to curtail the powers of the latter (e.g. by giving parliament a veto over the application of its decisions) or withdraw from the European Convention on Human Rights will feature in the 2015 Conservative manifesto.

Two objectives concerned immigration, which has become one of the most salient political issues. New mechanisms to prevent 'vast migrations' when new members join the EU, is not an issue of immediate concern. Restricting the right of EU migrants to claim welfare benefits is, however, the most significant and difficult to achieve of Cameron's objectives. The issue came to the fore as temporary restrictions on migrants from Bulgaria and Romania working in the UK expired in 2014. In a speech in November 2014, Cameron identified a series of changes he wants to be made to the rules on free movement of EU citizens, including further restrictions on entry 
and access to benefits plus tougher measures to deport criminals (Cameron, 2014b). Some of the changes proposed would require treaty change. Proposals for an 'emergency brake' or cap on the number of National Insurance numbers issued to EU migrants had been floated but ultimately did not feature in the speech after criticism from other Member States. Although some states share UK concerns about EU migrants' access to welfare benefits, few would countenance undermining the principle of free movement.

The goals of 'businesses liberated from red tape' and 'greater free trade with North America and Asia' are long-standing, and some progress is evident. Again, however, a danger is that the politics of support and politics of power pull in different directions. Business does not speak with one voice on the EU with organisations such as Business for Britain (2015) favouring extensive renegotiation. However, significant sections of UK business and the City, while supportive of Cameron's reform agenda, contend that withdrawal would be damaging (Confederation of British Industry, 2013; TheCityUK, 2013). If demands for withdrawal or fundamental renegotiation continue to grow on the Conservative benches, then strains in the relationship between the party, business and the City will become more apparent. On the single market and free movement, the Conservative leadership may ultimately be forced to make a strategic choose between its historic roles as the party of British capitalism and party of the nation state.

\section{'In-out' referendum}

Cameron's commitment to an 'in-out' referendum was a significant policy change. He had previously opposed a vote on EU membership, imposing a three-line whip on the October 2011 referendum motion. Having fuelled then disappointed Eurosceptic expectations on a popular vote - backtracking on a Lisbon Treaty referendum then designing a 'referendum lock' that would not be used in the current parliament - Cameron could no longer hold back the tide. 
Governing parties may propose a referendum on the EU in order to defuse a divisive issue, remove it from the parliamentary arena where intra-party divisions make a majority doubtful, respond to public demand, bring electoral advantage and legitimate a party's position on European integration (Oppermann, 2013). Cameron's referendum pledge may provide electoral advantage as both a positional and valence issue if voters conclude that only the Conservatives are promising and can deliver renegotiation and a referendum. Cameron's position is in tune with public opinion. When asked if they would vote to leave or remain should Cameron renegotiate the UK's relationship with the EU, a majority of respondents in YouGov polls conducted since 2013 say that they would vote to remain in the EU. Parallels are evident with the 1975 referendum on the EEC when Harold Wilson persuaded voters that he had negotiated a better deal for the UK even though the changes he secured were limited. Convincing his party may prove more difficult for Cameron. Intra-party divisions will intensify prior to the campaign if renegotiation is limited, and divided parties that send out mixed messages to voters find it difficult to mobilise their supporters (Gabel and Scheve, 2007). Cameron would hope that a decisive 'yes' vote would settle the EU issue for the foreseeable future, but further referendums may be required under the terms of the European Act 2011 and Eurosceptics are unlikely to retreat into the shadows. Ominously, Wilson's referendum could not prevent a split in the Labour Party.

\section{Conclusions: Is a Question the Answer?}

Cameron has been unable to strike the optimal balance between the politics of support and politics of power in relation to European integration. The prospects of forging a winning electoral coalition and establishing political leadership over the EU issue diminished as divisions in the Conservative Party intensified and support for UKIP increased. In the politics of power, the 
Eurozone sovereign debt crisis hastened the development of a multi-speed EU in which the UK is a more detached member.

Critics of Cameron's EU policy often claim that the mismatch between the politics of support and politics of power arose because he failed to tackle hard Euroscepticism within his party (Bale, 2011, 390). Problems in the politics of support are, however, only one element of the difficulties in Conservative statecraft. Governing competence, party unity and election victories are contingent upon successful management of the challenges and constraints of the politics of power. Just as unresolved problems in the politics of support create difficulties in the politics of power, so the reverse is true. Unless and until underling structural tensions in the UK's relationship with the EU are resolved, effective statecraft will prove elusive. Problems of choreography also made it difficult to Cameron to align the politics of support and politics of power. The Eurozone crisis necessitated a recalibration of relations with the EU, but the focus was on stabilising the euro not wider reform. Conservative Eurosceptics were impatient for change and, although most could in theory unite behind the renegotiation-referendum position, were already demanding more far-reaching reforms than Cameron envisaged.

Cameron's renegotiation-referendum position was borne from tactical considerations concerning party management and party competition. However renegotiation and a referendum may yet provide the elusive formula that marries the demands of the politics of support and politics of power. On the former, it offers a coherent and distinctive Eurosceptic position that is popular with voters and allows the Conservatives to outflank their rivals. If voters support a new settlement in a referendum, then Cameron's EU policy will gain added legitimacy and hard Euroscepticism will have been weakened. In relation to the politics of power, it provides the next Conservative government with a clear EU policy that is Eurosceptic but, with effective alliance-building, offers the prospect of the UK playing a constructive rather than spoiling role in an EU characterised by 
variable geometry. Should a new settlement with the EU be reached, it may provide both a clearer footing for the UK's relationship with the EU and for relations between Eurozone and nonEurozone states. A degree of executive autonomy would have been restored and Conservative political economy bolstered.

But Cameron's position also has risks. The extent of EU reform he wants or needs is not yet clear, but it is already apparent that some of the changes he has signalled will be difficult to achieve, particularly within the arbitrary timescale, and would not satisfy many Conservative MPs. Hague likened the EU issue to a ticking timebomb - a referendum could detonate it. The EU issue would dominate a second Cameron government and intra-party divisions will intensify as Eurosceptics up their demands, with further fratricidal blood-letting and defections to UKIP likely. Crucially, the fundamental strategic dilemma regarding the UK's position in the EU remains unresolved. As other Member States pursue further economic integration and the UK stays resolutely outside the Eurozone, the strategic choice may boil down to limited influence in a reformed EU or limited influence outside it. A growing number of Conservative MPs prefer the latter but important parts of the UK state and business, as well as major international allies, favour the former.

Conservative policy on European integration does not fit the pattern found in other policy areas of modernisation being developed rhetorically in opposition but then not executed in office (Dommett, 2015). Instead, the EU issue gained a higher profile and underwent greater change in government than in opposition. But Cameron was often reactive rather than proactive. He responded fitfully to developments in the EU, signalling his intention to forge a new settlement with a changing EU without offering coherent answers to some of the strategic questions they raised. Domestically, the Eurosceptic position was taken forward by harder Eurosceptics who pushed fundamental rengegoation and 'Brexit' from the fringes to the mainstream. Cameron was 
left playing catch-up, retreating to the traditional Conservative themes of immigration and the EU that he had deliberately downplayed in opposition.

The EU issue was largely absent at the birth of Cameron's modernisation project but, if the schisms in the Conservative Party and on the Right contribute to Conservative defeat in 2015, it will have played an important part in its demise. As John Major - who knows more than most about Conservative problems on the EU issue - argues, Cameron's renegotiation-referendum position may yet provide the optimal strategy for resolving both Conservative divisions and the UK's status in a changing EU (Major, 2013). But if the Conservatives lose the general election, Cameron's period in office may, like Major's, be remembered for intra-party divisions and declining British influence. A more Eurosceptic Conservative leader and position are then likely to emerge.

\section{References}

Baker, D., Gamble, A. and Seawright, D. (2002) Sovereign nations and global markets: modern British Conservatism and hyperglobalism. British Journal of Politics and International Relations 4(3): 399-428.

Bale, T. (2006) Between a soft and a hard place? The Conservative Party, valence politics and the need for a new 'Eurorealism'. Parliamentary Affairs 59(3): 385-400.

Bale, T. (2011) The Conservative Party from Thatcher to Cameron. Cambridge: Polity. Bale, T. (2012) The Conservatives since 1945. The Drivers of Party Change. Oxford: Oxford University Press.

Bale, T., Hanley, S. and Szczerbiak, A. (2010) 'May contain nuts'? The reality behind the rhetoric surrounding the British Conservatives' new group in the European Parliament. Political Quarterly 81(1): 85-98. 
Bulpitt, J. (1986) The discipline of the new democracy: Mrs Thatcher's domestic statecraft.

Political Studies 34(1): 19-39.

Bulpitt, J. (1992) Conservative leaders and the 'Euro-ratchet': five doses of scepticism. Political Quarterly 63(3): 258-75.

Business for Britain (2015) The Change we need. 10 Proposals for EU Reform. London: Business for Britain.

Byrne, C., Foster, E. and Kerr, P. (2012) Understanding Conservative modernisation. In T.

Heppell and D. Seawright (eds.) Cameron and the Conservatives: The Transition to Coalition Government. Basingstoke: Palgrave Macmillan, pp.16-31.

Cameron, D. (2006) Speech to the Conservative Party Conference, 1 October.

Cameron, D. (2007a) The EU: a New Agenda for the 21st Century. Speech to the Movement for European Reform, Brussels, 6 March.

Cameron, D. (2007b) Cameron: I'll give EU a vote. The Sun, 26 September.

Cameron, D. (2009) A European Policy that People can Believe In. Speech at Bloomberg,

London, 4 November.

Cameron, D. (2011) Foreign Policy in the National Interest. Speech at the Lord Mayor's Banquet, London. 14 November.

Cameron, D. (2013) EU speech at Bloomberg. London, 23 January.

Cameron, D. (2014a) The EU is not working and we will change it. Sunday Telegraph, 16 March.

Cameron, D. (2014b) Speech on immigration and the EU. Rocester, Staffordshire, 28 November.

Carlin, B. (2006) Off-the-cuff Cameron accuses UKIP of being ‘fruitcakes and closet racists'.

Daily Telegraph, 5 April.

Cash, W. and Jenkin, B. (2013) The EU Single Market - Is It Worth It?

http://conservativehome.blogs.com/files/the-single-market-is-it-worth-it.pdf

Confederation of British Industry (2013) Our Global Future. London: CBI. 
Copsey, N. and Haughton, T. (2014) Farewell Britannia? 'Issue capture' and the politics of David Cameron's 2013 EU referendum pledge. Journal of Common Market Studies 52(S1): 74-89.

Cowley, P. and Stuart, M. (2012) The Cambusters: the Conservative European Union referendum rebellion of October 2011. Political Quarterly 83(2): 402-6

Cowley, P. and Stuart, M. (2014) The Four-Year Itch. http://revolts.co.uk/wpcontent/uploads/2014/06/Four-year-itch_cover_full.pdf

Craig, P. (2011) The European Union Act 2011: locks, limits and legality. Common Market Law Review 48: 1915-44.

Daddow, O. (2015) Interpreting the outsider tradition in British European policy speeches from Thatcher to Cameron. Journal of Common Market Studies 53(1): 71-88.

Dashwood, A. (2013) The United Kingdom in a re-formed European Union. European Law Review 38(6):737-56.

Dommett, K. (2015) 'When I say change, I'm not talking about some slick re-branding exercise': the theory and practice of Conservative modernisation. British Politics 10(2).

European Council (2014) Conclusions 26/27 June. EUCO79/14. Brussels: European Council. European Mainstream (2014) In Our Interest: Britain with Europe. www.europeanmainstream.org.uk/in-our-interest-britain-with-europe/ European Scrutiny Committee (2013) Reforming the European Scrutiny System in the House of Commons. 24th Report, 2013-14.

Evans, G. (1998) Euroscepticism and Conservative electoral support: how an asset became a liability. British Journal of Political Science 28(4): 573-90.

Ford, R. and Goodwin, M. (2014) Revolt on the Right. Explaining Support for the Radical Right in Britain. London: Routledge.

Fresh Start Project (2012) Options for Change Green Paper. Renegotiating the UK's Relationship with the EU. www.eufreshstart.org/downloads/fullgreenpaper.pdf. 
Fresh Start Project (2013a) Manifesto for Change.

http://eufreshstart.org/downloads/manifestoforchange.pdf

Fresh Start Project (2013b) Mandate for Reform.

http://eufreshstart.org/downloads/mandateforreform.pdf

Gabel, M. and Scheve, K. (2007) Mixed messages: party dissent and mass opinion on European integration. European Union Politics 8(1): 37-59.

Gamble, A. (1994) The Free Economy and the Strong State. The Politics of Thatcherism. $2^{\text {nd }}$ edition. London: Palgrave Macmillan.

Gifford, C. (2014) The people against Europe: the Eurosceptic challenge to the United

Kingdom's coalition government. Journal of Common Market Studies 52(3): 512-28.

Goes, E. (2014) The coalition and Europe: a tale of reckless drivers, steady navigators and imperfect roadmaps. Parliamentary Affairs 67(1): 45-63.

Hannan, D. (2014) David Cameron has dropped the idea of a new deal - the EU referendum will be on the existing terms. Daily Telegraph blog, 13 June,

http://blogs.telegraph.co.uk/news/danielhannan/100276242/david-cameron-has-dropped-the-ideaof-a-new-deal-the-referendum-will-be-on-the-existing-membership-terms/

Heppell, T. (2013) Cameron and liberal conservatism: attitudes within the parliamentary Conservative Party and Conservative ministers. British Journal of Politics and International Relations 15(3): 340-61.

HM Government (2010) The Coalition: Our Programme for Government. London: The Cabinet Office.

HM Government (2013) Decision Pursuant to Article 10 of Protocol 36 to the Treaty on the Functioning of the European Union. CM8671. Norwich: The Stationery Office.

HM Treasury (2014) European Union Finances 2014: Statement on the 2014 EU Budget and Measures to Counter Fraud and Financial Mismanagement. Cm 8974. London: HM Treasury. Kenny, M. and Smith, M. (1997) (Mis)understanding Blair. Political Quarterly 68(3): 220-30. 
Kirkup, J. (2010) David Cameron says he is a 'Eurosceptic' following EU 'deal', Daily Telegraph, 29 October.

Lynch, P. (1999) The Politics of Nationhood. Sovereignty, Britishness and Conservative Politics. London: Palgrave Macmillan.

Lynch, P. and Whitaker, R. (2008) A loveless marriage. The Conservatives and the European People's Party. Parliamentary Affairs 61(1): 31-51.

Lynch, P. and Whitaker, R. (2013a) Where there is discord, can they bring harmony? Managing intra-party dissent on European integration in the Conservative Party. British Journal of Politics and International Relations 15(3): 317-339.

Lynch, P. and Whitaker, R. (2013b) Rivalry on the right: the Conservatives and the UK Independence Party (UKIP) and the EU issue. British Politics 8(3): 285-312.

Major, J. (2013) The Referendum on Europe: Opportunity or Threat? Speech at Chatham House, 14 February.

McAnulla, S. (2010) Heirs to Blair's third way? David Cameron's triangulating conservatism. British Politics 5(3): 286-314.

Oppermann, K. (2008) The Blair government and Europe: the policy of containing the salience of European integration. British Politics 3(2): 156-82.

Oppermann, K. (2013) The politics of discretionary government commitments to European integration referendums. Journal of European Public Policy 20(5): 684-701.

Osborne, G. (2014) Speech to the Open Europe Conference. London, 15 January.

Taggart, P. and Szczerbiack, A. (2008) Theorising party-based Euroscepticism: problems of definition, measurement and causality. In P. Taggart and A. Szczerbiack (eds.) Opposing Europe. The Comparative Party Politics of Euroscepticism. Volume 2. Oxford: Oxford University Press, pp.238-62.

TheCityUK (2013) UK and the EU: A Mutually Beneficial Relationship. London: TheCityUK. 
Webb, P. and Bale, T. (2014) Why do Tories defect to UKIP? Conservative Party members and the temptations of the populist radical right. Political Studies 62(4): 961-70.

Wellings, B. (2012) English Nationalism and Euroscepticism. Losing the Peace. London: Peter Lang.

Whitaker, R. and Lynch, p. (2014) Understanding the formation and actions of Eurosceptic groups in the European Parliament: pragmatism, principles and publicity. Government and Opposition 49(2): 232-63. 